\title{
A worthy tribute to a South African giant
}

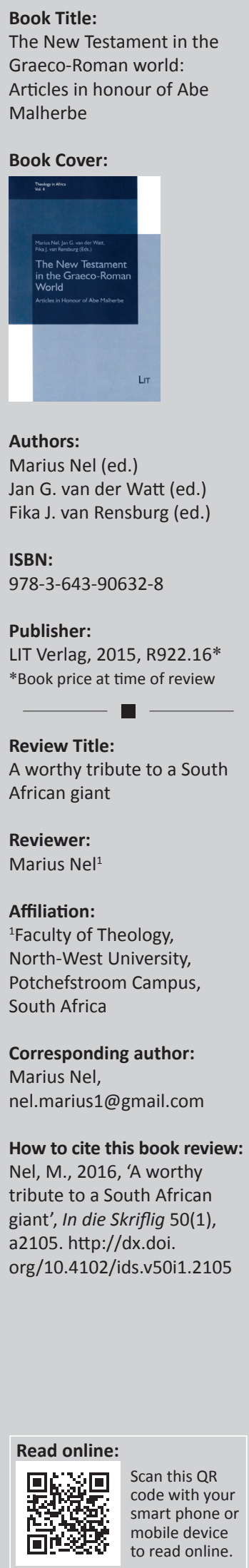

This book in honour of Professor Abe Malherbe is the product of South African and international scholars paying tribute to the memory of a great New Testament scholar working in the USA and with great influence especially in South Africa.

On 01 August 2013 North-West University in Potchefstroom, South Africa hosted an Abe Malherbe Memorial Seminar under the chairmanship of Professors Fika J. van Rensburg, Dean of the Faculty of Theology, and Jan G. van der Watt of Radboud University and associated with the North-West University.

This Festschrift is the product of the Seminar with South African and international scholars honouring the memory of a great New Testament scholar influencing the practice of the science of the New Testament internationally and in the country of his birth.

Abraham Johannes (Abe) Malherbe (15 May 1930-28 September 2012) was born in Pretoria. He studied at the Abilene Christian University in the USA, the training centre of the Churches of Christ, and Harvard in Boston. He completed his doctorate in 1963 under the supervision of Professor Helmut Koester. Malherbe was known for his love for the text, his thoroughness, and a pursuit of excellence in his exegesis, traits that became his academic characteristics. As a member of The Society of Biblical Literature for over 50 years, he was a highly productive scholar who made major contributions in several areas.

He served as Associate Professor in New Testament and early Christianity at the Abilene Christian University from 1963 to 1969 where he specialised in the Greek philosophical and religious background of the New Testament. He became one of the first of his generation to unlock the social dynamics of the Graeco-Roman ancient texts for New Testament research. His knowledge about the ancient social world and the accompanying resources was unequalled among New Testament scholars of his time, allowing him to play a leading role in the development of a social understanding of New Testament texts. As Doktorvater for many prominent scholars he influenced them by showing how writers in the New Testament utilised a whole range of moral philosophical sets of ideas (topoi) in the ancient ethical tradition of Greek descent. He was invited to lecture at Harvard University (1967-1968) and in 1970 he was appointed lecturer at the Yale School of Divinity and since 1981 as the prestigious Buckingham professor, until his retirement in 1994.

Professor Jan van der Watt writes the following of his friend, Professor Malherbe: his faith remained central in his life and he had the ability to balance the possible tension between his faith and his academic activity. He was also intensely involved in church activities, as preacher and adult teacher.

The 14 essays cover a variety of themes and illustrate the pervading influence of Malherbe when colleagues and friends salute him. Van der Watt evaluates Bruce Malina's response to Malherbe in a discussion of 3 John and hospitality; Cilliers Breytenbach shows how Malherbe crossed barriers in New Testament studies; and Andries van Aarde reads Romans 12 pragmaticlinguistically in an attempt to demonstrate Malherbe's emphasis that Paul uses a style adopted from the moral philosophers of his day. This method of Paul culminates in an expression of joy that his converts still hold as the moral example to which they look for guidance. The other articles also demonstrate in what way Malherbe served as a role model for his South African colleagues, with Jan du Rand writing about the animal imagery in Revelation 16 as the apocalyptic enemies of God; and Kobus Kok about Christology in Colossians as a product of the Dialogical Self Theory that Malherbe introduced him to as a heuristic tool in New Testament Studies. Jeremy Punt mentions that it is Malherbe's work on the intersection between New

Copyright: @ 2016. The Authors. Licensee: AOSIS. This work is licensed under the Creative Commons Attribution License. 
Testament documents and the ancient philosophical context(s) that continues to stimulate his own endeavours for further conceptual clarification regarding the nexus between the New Testament and the Roman Empire. Gregory Sterling of Yale Divinity School writes on the social apology of Luke-Acts consisting of a dialectical relationship between allegiance to the values of Christianity and the need to take a place in the world, with Malherbe personifying this dialectic, reaching the highest levels of academic achievement yet never forgetting the values of his religious tradition.

A compilation of essays by different authors always imply that the quality of the work also differs, although it also allows for a diverse group of readers. However, in these articles one finds a good standard of academic work and the book succeeds in its goal of demonstrating the lasting influence of a South African son who enjoyed the highest international acclaim. 